\title{
STUDY OF STABLE NITROGEN FORMS IN NATURAL SURFACE WATERS IN THE PRESENCE OF MINERAL SUBSTRATES
}

\author{
Petru Spataru* ${ }^{a *}$ Igor Povar ${ }^{\mathrm{a}}$, Elena Mosanu ${ }^{\mathrm{b}}$, Ana Trancalan ${ }^{\mathrm{a}}$ \\ ${ }^{a}$ Institute of Chemistry of Academy of Sciences of Moldova, 3, Academiei str., Chisinau MD-2028, Republic of Moldova \\ ${ }^{b}$ Institute of Ecology and Geography of Academy of Sciences of Moldova, 1, Academiei str., \\ Chisinau MD-2028, Republic of Moldova \\ *e-mail: spatarupetru@yahoo.com
}

\begin{abstract}
The influence of substrates on the oxidation of reduced toxic forms of nitrogen in river water was investigated by laboratory modelling. Granite and expended clay accelerate the oxidation of ammonium and nitrite ions from 2 to 4 times. The presence of calcium carbonate in water hinders the oxidation of nitrogen in the polluted water.
\end{abstract}

Keywords: granite, expanded clay, calcium carbonate, ammonium, nitrite.

Received: May 2014/ Revised final: September 2015/ Accepted: November 2015

\section{Introduction}

Experimental data regarding mineral forms of nitrogen, hydrochemistry research and water quality of large and small rivers in the Republic of Moldova have been published in a number of revues [1,2]. A key reason for the research of mineral nitrogen is the toxicity of the different forms of its mineral and especially reduced forms. A bibliographic review shows that for a wide range of bacteria, in contrast to the situation in animal [3] and plant cells [4,5], ammonium is not toxic, even up to $1 \mathrm{~mol} / \mathrm{L}$ of synthetic solutions [6]. This happens because the most bacteria prefer ammonium as a nitrogen source; some species even produce ammonium ion, for example $\mathrm{N}_{2}$-fixing Rhizobia Cyanobacteria and Proteolytic Clostridia produce ammonium through the fermentation of aminoacids. Resistance to ammonium is a common property in terms of bacteria [6]. However, nitrites are highly toxic to humans, flora and fauna, being an important concern regarding water quality. Nitrites are also involved in the pathology of gastric cancer $[7,8]$ and are a possible cause of migraines [9]; they also compromise the binding capacity of oxygen in the blood and may result in respiratory deficiencies of aquatic animals and humans $[10,11]$. Understanding the toxicity of reduced forms of nitrogen requires the identification of methods of enhancing the oxidation of the nitrification process. Changing forms of nitrogen in surface water objects have been extensively studied. Pollution sources related to human activities have an obvious impact on the processes of nitrification and denitrification (oxidation of ammonia, nitrite and nitrate reduction etc.). Hu X.M. et al. reported the removal rates of $\mathrm{NH}_{4}^{+}-\mathrm{N}$ during the nitrification-denitrification process and the total nitrogen (TN) reached $94 \%$ and $82 \%$, respectively. From the mass balance, it followed that $87 \% \mathrm{of} \mathrm{NH}_{4}^{+}-\mathrm{N}$ was removed by shortcut nitrification [12]. In a series of previous publications the process of the oxidation of reduced forms of nitrogen in surface water using pebbles, polymer film and aeration was investigated [13]. These papers reported changes of nitrogen forms in surface waters. The gravel and polymeric film in addition with aeration have the effect of decreasing the concentration of ammonium ions in water. Pebbles and polymeric film speed the oxidation of ammonium, while aeration diminishes its quantity in another way. This research is a continuation of the aforementioned studies.

\section{Materials and methods}

In 2012, a number of water samples were taken from the Nistru River in May and its tributaries (rivulet near the Racovatul de Sud village in January, rivulet near the Cunicea village in May) and from the Prut River in June, as well as from the Isnovat rivulet in October. The tests of natural water were performed according to ISO methods published in specialized literature [14-19]. Laboratory trials were initiated in glass vessels and respected the minimum recommended water-sample model volume (3L). The same volume and conditions for the whole series of samples from laboratory simulation experience are essential [20]. A solution of $\left(\mathrm{NH}_{4}\right)_{2} \mathrm{SO}_{4}$ or $\mathrm{NH}_{4} \mathrm{Cl}$ was added to each sample to obtain the ammonium ion concentrations between 1.75 and $2.5 \mathrm{mg} / \mathrm{L}$.

The substrate constituted a fourth part of the total volume of each water samples. It was used $1.0-2.5 \mathrm{~mm}$ of the substrate granulometric fraction. In the samples 2 grams of chemically pure fine powder of $\mathrm{CaCO}_{3}$ were added. The purity of all used substances corresponded to the ISO requirements [14-18]. Model water samples were kept in natural lighting and away from direct sunlight. Laboratory simulations were performed under the static conditions. The stirring was done after each test series. The tests were completed at the same day time.

Contents of ammonium and nitrite ions were determined by standard methods (Nessler and Griess reagents), using the HACH Spectrophotometer DR/2500 and UV-VIS. The contents of ammonium and nitrites in natural water were taken into account in all laboratory simulations. 


\section{Results and discussion}

The study has been carried out both in small and large rivers, in sections with different pollution levels. The process of oxidation of reduced nitrogen in water from the rivulet near the Racovatul de Sud village, collected in January with granite and clay porous substrates, has been experimentally proved.

The presence of granite and clay foam accelerates the oxidation of ammonium ions to the level below its maximum allowable concentration (MAC) during 7-8 days, and under the limit of quantification by 11 days (Figure 1a). Ammonium ions oxidation in the presence of granite has an insignificant delay compared with that in the presence of expanded clay samples, but the formation of nitrite ions and its decreasing concentrations in the same samples delay by 3-4 days, exceeding MAC of about $1 \mathrm{mg} / \mathrm{L}$ (Figure $1 \mathrm{~b}$ ). The nitrite concentration in reference sample under the same conditions reaches maximum with a delay of 31 days, after which it decreases and subsequently begins again to raise. After 59 days, within the realized simulation in the reference samples (without substrates) the significant final reduction of $\mathrm{NO}_{2}$ - does not achieve. Multiple laboratory simulations of water from different rivers in winter conditions, similar to reference samples, were carried out to ensure that braking reduced nitrogen oxidation in winter samples was not an incidentally event. In the same way the impact of granite and keramzite was tested. This blocking effect is evident for both of cases of ammonium oxidation and more obvious of the oxidation stage of nitrites to nitrates. We should mention after 20-30 days there have not been registered any significant changes, even the results presented below were obtained in 59 days.

Spring samples from the Nistru River and the rivulet near the Cunicea village have been investigated by means of a similar model, using both water samples in the presence and absence of $\mathrm{CaCO}_{3}$. The changes described in Figure $2 \mathrm{a}$ show that in the presence of $\mathrm{CaCO}_{3}$ the braking of the ammonium ions oxidation takes place. The decreasing the nitrite amount due to its slow formation is similar in the water samples taken from the Nistru River, section Varancau.
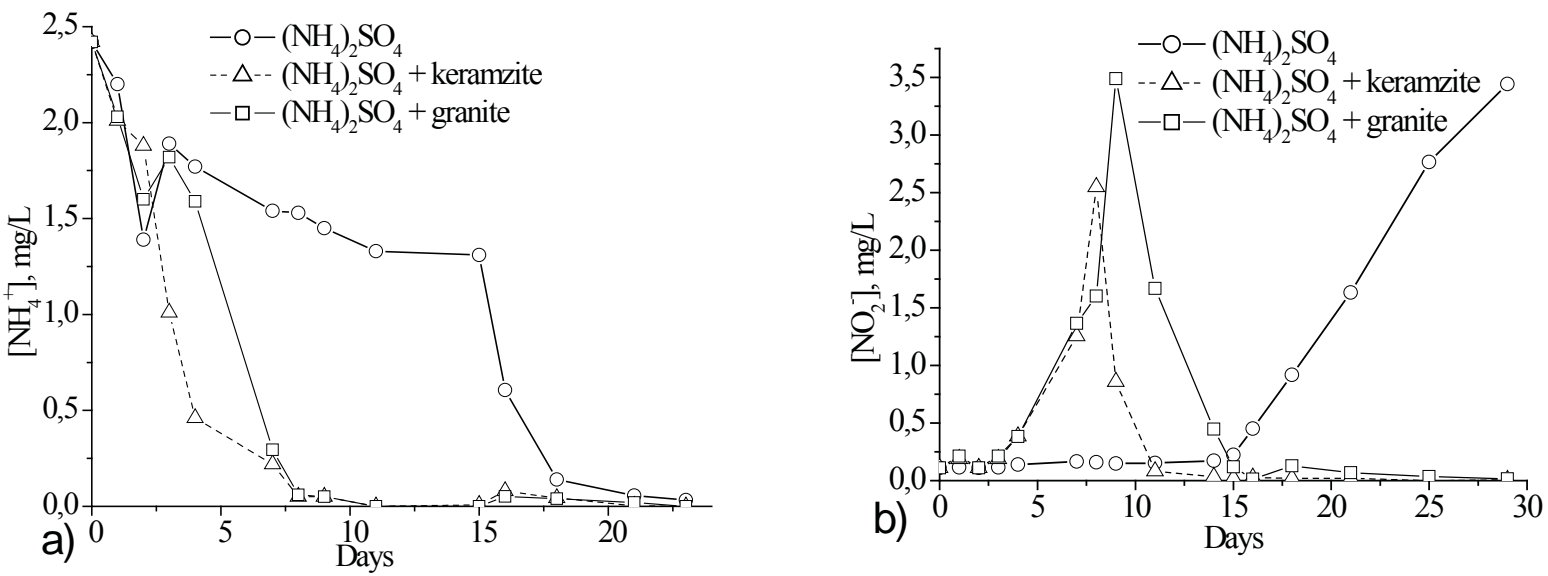

Figure 1. Dynamics of ammonium ion (a) and nitrite ion (b) concentrations in water samples collected from the rivulet near the Racovatul de Sud village in January 2012.
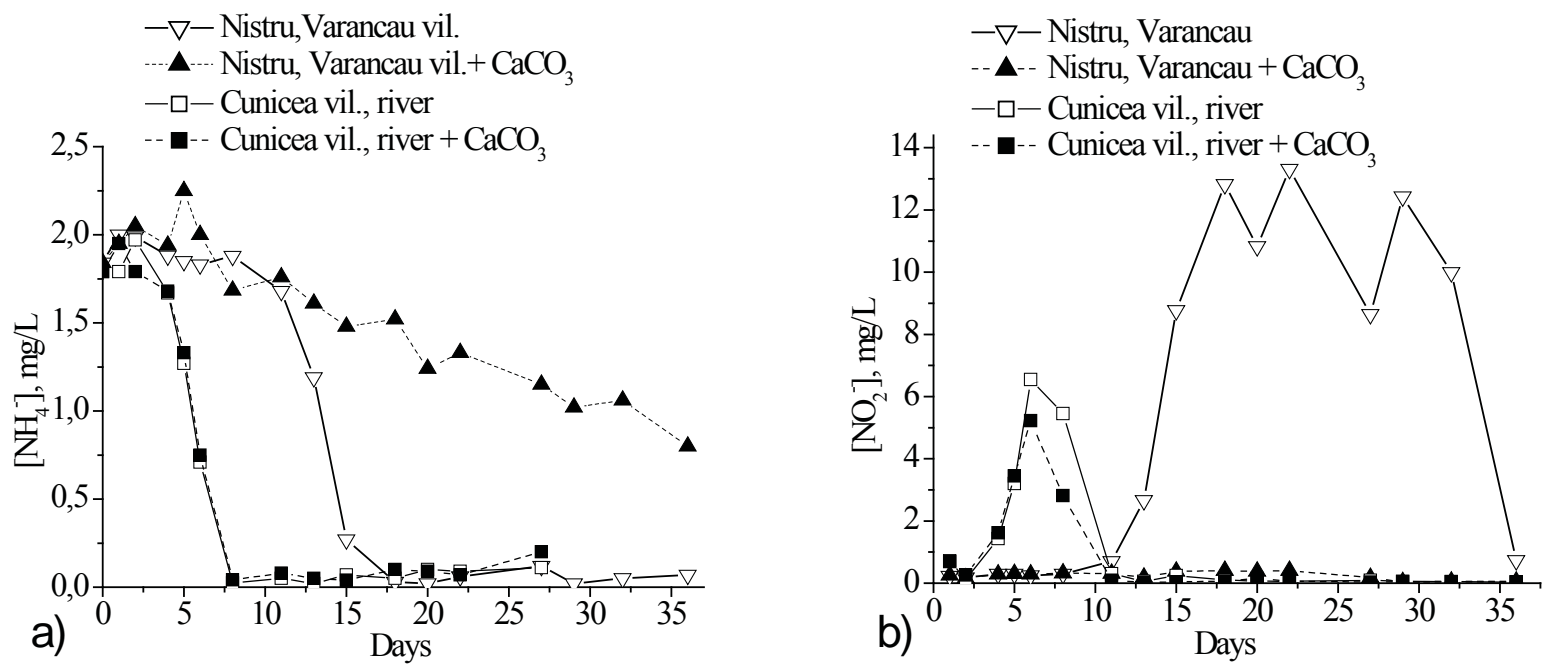

Figure 2. Dynamics of ammonium ion (a) and nitrite ion (b) concentrations in water samples taken from the Nistru River, section Varancau and the rivulet near the Cunicea village in May 2012. 
The Nistru River, downstream of the Soroca city (section Varancau) is obviously polluted by sewage. Thus, the difference of cationic detergents amounts between the samples of Nistru River, in Varancau and the Cunicea village is easily explained. In the sample without the substrate, nitrification is significant, obtaining high concentrations (12-14 mg/L) of nitrites [21,22]. Formation of considerable quantities of nitrites shows that from day 11 to day 30 the rate of oxidation of ammonium ions and the $\mathrm{NO}_{3}^{-} \rightarrow \mathrm{NO}_{2}^{-}$reduction exceeds the nitrite ions oxidation $\mathrm{NO}_{2}{ }^{-} \rightarrow \mathrm{NO}_{3}^{-}$[23].

In the sample with $\mathrm{CaCO}_{3}$, the ammonium ions oxidation is stopped. At the same time the level of $0.4 \mathrm{mg} / \mathrm{L}$ of nitrite ions concentration, as for nitrate ions concentration, remains invariable in the analyzed sample within the studied period of time. Thus, the ratio of the maximum concentrations of nitrites in model samples with and without $\mathrm{CaCO}_{3}$ (Nistru River, section Varancau) is larger by almost two orders of magnitude. In the same figure, the dynamics of the concentrations of $\mathrm{NH}_{4}^{+}$and $\mathrm{NO}_{2}^{-}$ions for river near the Cunicea village, whose waters do not contain synthetic surfactants, is also depicted. The oxidation of ammonium ions in the rivulet water of the Cunicea village is similar in both samples (with and without $\mathrm{CaCO}_{3}$ ). The difference between the indices of nitrite ions in these samples reveals that calcium ions bind some water-soluble organic substances, and therefore has a small slowing effect on the rate of $\mathrm{NO}_{2}^{-}$ oxidation to nitrates, or causes nitrate ions reduction.

Water samples of the Nistru River at the Bursuc village (Figure 3), which is downstream of the Varancau village, are less polluted that can be explained by the sedimentation processes of suspended particles. A part of the organic matter is precipitated by cationic surfactants, which therefore remain in smaller quantities in water. The braking effect is evident in the Nistru River (section Bursuc) samples in presence $\mathrm{CaCO}_{3}$, but less than the last-mentioned ones. The water sample collected in summer from the Sculeni section of the Prut River was less polluted, and those sampled downstream of the Ungheni city after wastewater treatment plants (WWTP) was more polluted, giving to the braking effect a perceptibly different value. In the last of samples mentioned above, by the addition of $\mathrm{CaCO}_{3}$, the impediment of the nitrification process was practically complete.

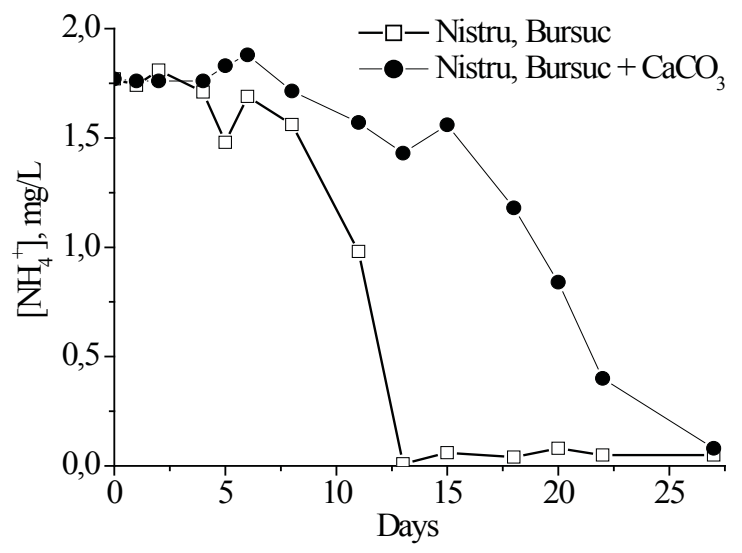

Figure 3. Dynamics of ammonium ion concentrations in water sample collected from the Nistru River (section Bursuc) in May 2012.

In the samples from the Ungheni section (Prut River), as in the Nistru River, section Varancau, the ratio between the maximum nitrite ion concentrations with and without calcium carbonate is about two orders. In polluted samples of the Nistru and Prut Rivers with added $\mathrm{CaCO}_{3}$, the formation of nitrite ions is mostly likely due to the reduction of nitrate ions than to the oxidation of ammonium ions to form $\mathrm{NO}_{2}^{-}$. The toxic properties of some pollutants (mostly probably cationic organic substances) are amplified in the presence of calcium carbonate within laboratory simulations. For the samples taken from the Nistru and Prut rivers, downstream cities, where massive amounts of effluents from sewage treatment plants reach their waters, the abovementioned phenomenon is revealed. Wastewaters accumulated in the treatment plants are mostly of domestic origin. So, the large amounts of pollutants in wastewaters constitute synthetic detergents. Previous research [24] proved that anionic and non-ionic surface-active substances at the MAC level decreased by a smaller amount the speed of the nitrification process. It is known that the process of the nitrogen oxidation is delayed in the presence of cationic surfactants and amines. This process has been also studied in the case of the mixture of cationic and anionic detergents [24]. For such mixture, the toxicity of cationic surfactants decreases [21,22]. On the contrary, the toxicity of cationic surfactants amplifies with the water hardness increasing [25]. The phenomenon of the nitrification braking in the presence of $\mathrm{CaCO}_{3}$ is characteristic for the water sections collected downstream WWTP of cities. In the presence of mixtures of cationic and anionic surfactants, a preferential binding of anionic surfactants to calcium carbonate particles has been found [26,27]. Consequently, it can be assumed that the decomposition of the associates formed from anionic and cationic surfactants contribute to braking of the 
nitrogen oxidation. This decomposition was performed by treatment with fine powder of $\mathrm{CaCO}_{3}$. In waters there are remained soluble surface-active cationic substances which manifest bactericidal effect. The enzymes concentration, which accelerates the nitrogen oxidation, decreases. Thus, the influence of $\mathrm{CaCO}_{3}$ on the investigated processes can be understood. Additionally, it is expected to suppose the formation of associates of $\mathrm{CaCO}_{3}$ with anionic organic species, $\mathrm{NH}_{4}^{+}$and $\mathrm{NH}_{2} \mathrm{OH}$, which could also lead to braking of the $\mathrm{NH}_{4}^{+} \rightarrow \mathrm{NO}_{2}^{-}$process [21,23]. This is one of two possible causes that might decrease the nitrite ions concentration. The second cause could be shrinking the soluble organic matter due to its sedimentation on the solid particles of $\mathrm{CaCO}_{3}$, decreasing the speed of the $\mathrm{NO}_{3}^{-} \rightarrow \mathrm{NO}_{2}^{-}$process.

The same phenomenon was registered for the samples taken in the Prut River close to Sculeni village. Within the areas of the Prut River at the Ungheni city and the Sculeni village, the presence of $\mathrm{CaCO}_{3}$ has a smaller influence on the ammonium ion oxidation process (Figure 4a). In the rivulet flowing through the Cunicea village, where detergents are absent, the samples with and without $\mathrm{CaCO}_{3}$ show the same nitrification path for both the dynamics of ammonium oxidation and variation of nitrite ion concentrations. Obviously, it has to be taken into account that nitrite ions could appear due to reduction of nitrate ions, especially for polluted waters containing more organic substances, which are able to act as reducing agents. That is why in the samples taken from the Nistru River, section Varancau (Figure 2), from the Prut River, section Sculeni and the Prut River after WWTP (Figure 4) the nitrite ions are found to be in higher concentrations that they could be formed from the ammonium oxidation.

The impact of granite, keramzite, calcium carbonate and their mixture on the water samples collected from the Isnovat River in October was investigated. These studies demonstrate that granite, keramzite and their mixture have a stimulatory influence on nitrification dynamics (Figures 5 and 6). These cases are similar to those of winter samples.
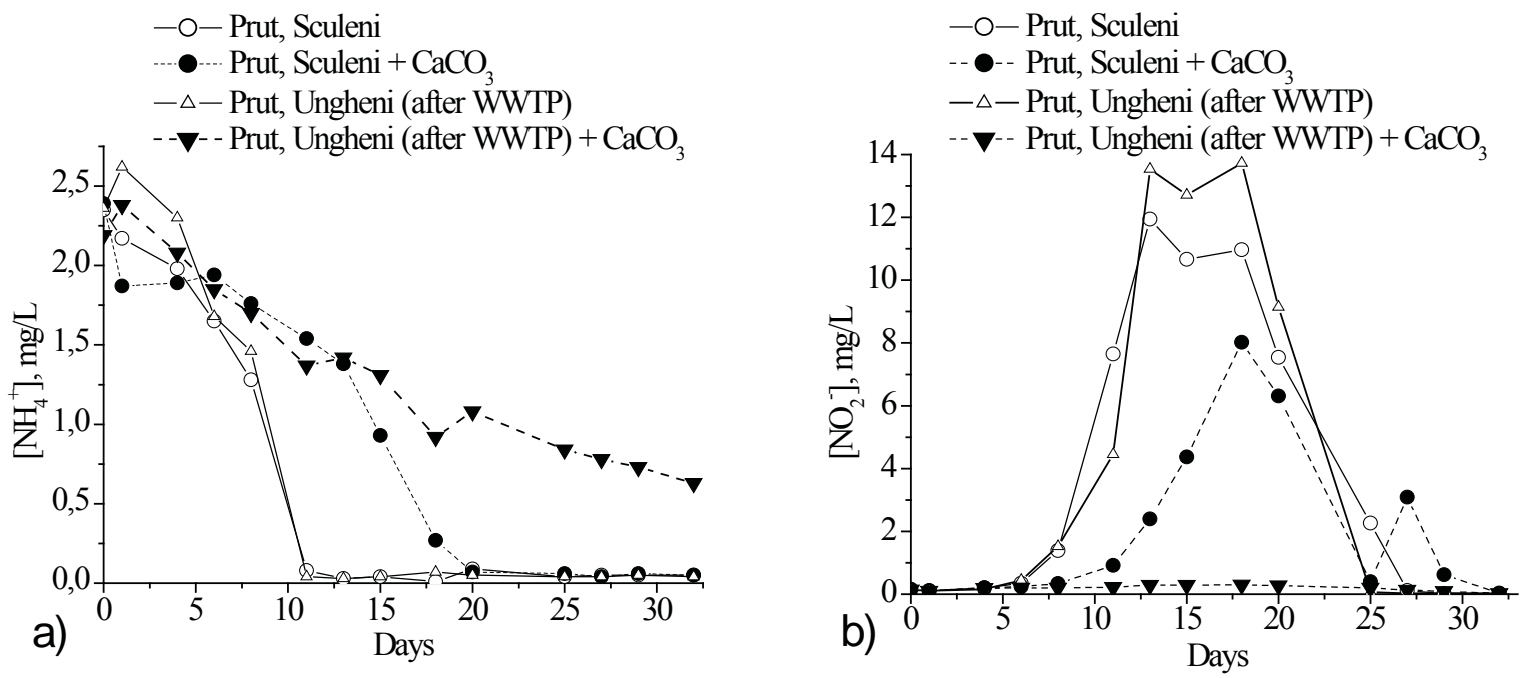

Figure 4. Dynamics of ammonium ion (a) and nitrite ion (b) concentrations in water samples collected from the Prut River, Sculeni section and after WWTP in June 2012.
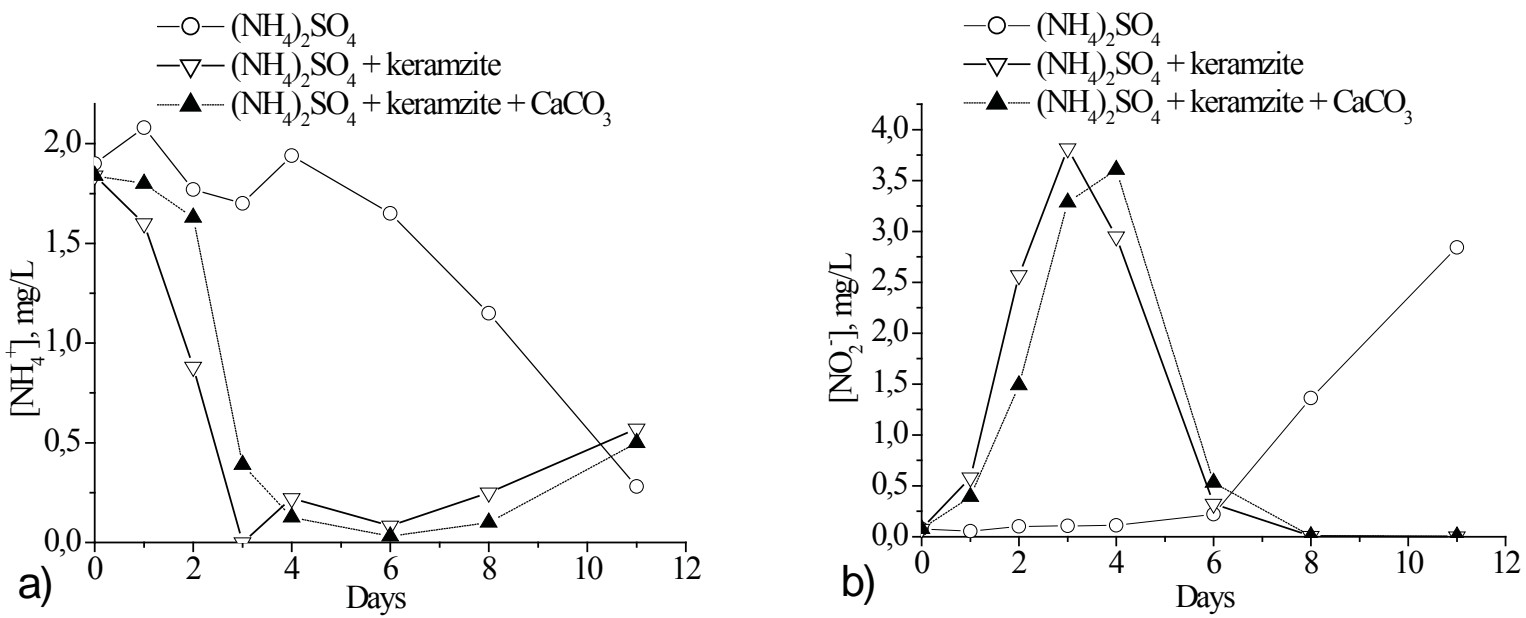

Figure 5. Dynamics of ammonium ion (a) and nitrite ion (b) concentrations in the presence of keramzite and $\mathrm{CaCO}_{3}$ in the water samples taken from the Isnovat River in October 2012. 
The dependence of ammonium ion concentrations on the time demonstrates the stimulation of the ammonium ions oxidation in the presence of granite, compared to the reference sample (e.g. the sample of natural water to which was initially added $2 \mathrm{mg} / \mathrm{L}$ of ammonium ions).

It should be noted that the rates of ammonium ions oxidation of reference samples and those with calcium carbonate are very close (Figures 5 and 6). In the last samples taken from the Isnovat River the decreasing the ammonium ion amounts has an insignificant delay, dissimilar for samples of the Nistru River (spring) and the Prut River (summer). The difference is only in the dynamics trend of nitrite ion concentrations and their values. When in the reference sample the nitric index just starts to increase, in the sample with $\mathrm{CaCO}_{3}$, it reaches the maximum value. Accordingly, in the last case, the maximum value (on the eighth day) is $1.3 \mathrm{mg} / \mathrm{L}$, while for the reference sample it is reached after 11 days of the model initiation with a maximum value of $3.01 \mathrm{mg} / \mathrm{L}$. A significant delay occurs in the case of granite and calcium carbonate mixture. In these samples, the nitrite ions concentration achieves the highest peak. Conversely, the nitrite ions concentration in the sample with granite and $\mathrm{CaCO}_{3}$ separately, are among the lowest ones. Unlike the water sample containing expanded clays with calcium carbonate, the ammonium ions oxidation occurs analogously as with the keramzite sample.
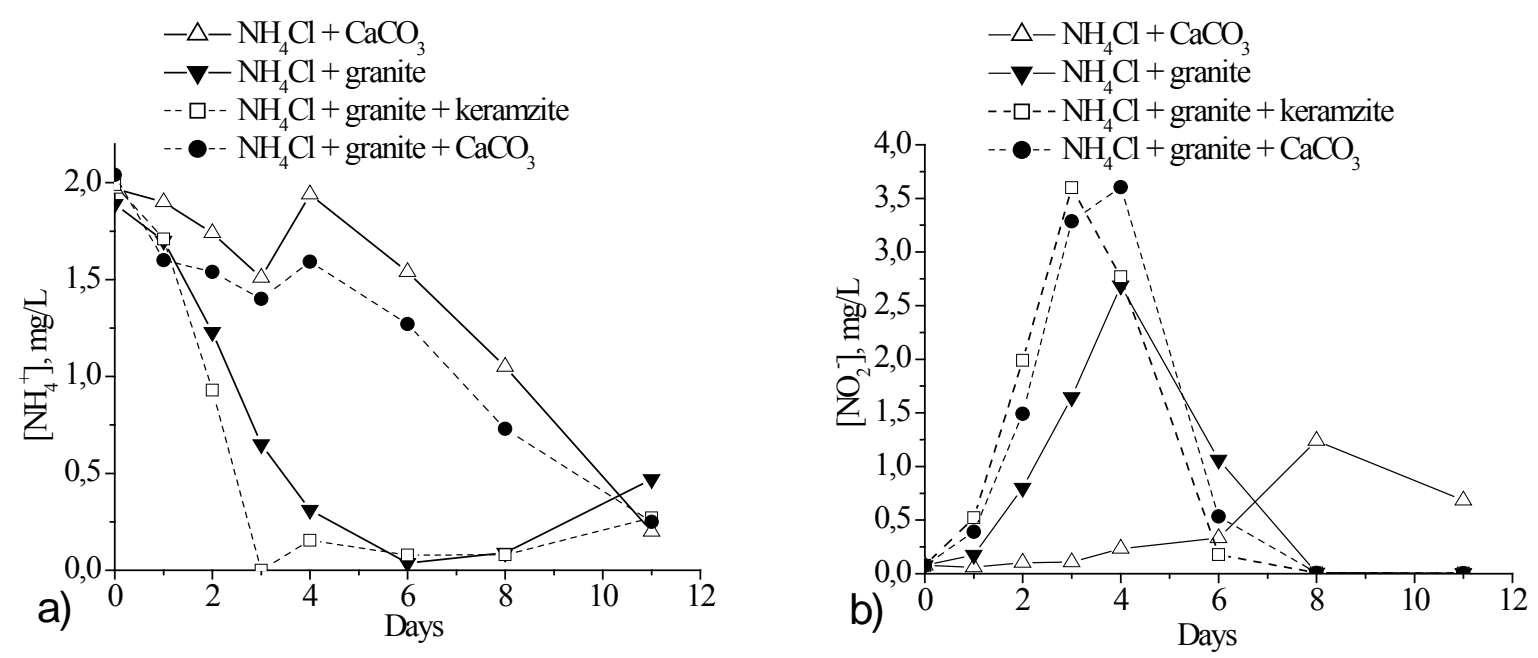

Figure 6. Dynamics of ammonium ion (a) and nitrite ion (b) concentrations in models with granite and $\mathrm{CaCO}_{3}$ only, mixtures of granite and keramzite or granite and $\mathrm{CaCO}_{3}$ in the Isnovat River waters collected in October 2012.

The obtained results (see all figures) show increasing or decreasing the blocking phenomena (stimulating oxidation of nitrogen reduced forms in river waters) in polluted samples in the presence of suspended particles of calcium carbonate, keramzite and granite substrates. The stimulate effect of nitrogen oxidation has been explained by authors $[25,28,29]$ through the adsorption of cationic surfactants on the surfaces of granite and expanded clay. Additionally, the phenomenon of adsorption of ammonium ions onto the surface of calcium carbonate itself or in combination with other low cost adsorbents from polluted waters was revealed in a series of published works [30-32]. Unfortunately, all above mentioned papers do not contain a rigorous explanation about the mechanism of observed phenomena. This question will constitute an objective of our next communication.

Finally, it is interesting to mention the assumption of authors [27] that even the $\mathrm{CaCO}_{3}$ nanoparticles are almost insoluble in water, once dispersed in water the $\mathrm{Ca}-\mathrm{OH}$ group can be formed on the particle surface, which may become either positively $\left(\mathrm{Ca}_{-} \mathrm{OH}_{2}^{+}\right)$or negatively $\left(\mathrm{Ca}-\mathrm{O}^{-}\right)$charged by combining or releasing a proton, depending on the $\mathrm{pH}$ of medium. For example, being dispersed in pure water, the $\mathrm{pH}$ of the dispersion is 9.93 , indicating that the $\mathrm{CaCO}_{3}$ nanoparticles are positively charged in neutral water.

\section{Conclusions}

Granite and keramzite substrates, separately and in their mixtures, show a similar effect in assisting the oxidation of nitrogen reduced forms in natural surface waters, accelerating the oxidation of ammonium and nitrite ions from 2 to 4 times.

Calcium carbonate in its mixtures with granite or expanded clays (compared to samples containing separate substrates) in the river waters slows in a different way the oxidation of ammonium nitrogen, while it causes no braking 
nitrification in non-polluted water. The impact of expanded clay, granite substrates and $\mathrm{CaCO}_{3}$ is comparable for samples collected in different seasons.

Organic pollutants, especially the cationic surfactants, coming from the urban activities, in the presence of calcium carbonate produce a clear impact on the braking process of oxidation of nitrogen reduced forms in natural waters.

\section{References}

1. Gladchi, V.; Goreaceva, N.; Duca, G.; Bunduchi, E.; Borodaev, R.; Mardari, I.; Romanciuc, L. Chemical composition and redox state of medial Nistru waters. Environment, 2008, 3(39), pp. 20-28 (in Romanian).

2. Zubcov, E.; Bagrin, N.; Ungureanu, L.; Bilețchi, L.; Borodin, N.; Bogonin, Z. The dynamic of hydrochemical indexes and quality of the Prut river. The Bulletin of Academy of Science of Moldova, Life Science, 2011, 313(1), pp. 103-110 (in Romanian).

3. Martinelle, K.; Häggström, L. Mechanisms of ammonia and ammonium ion toxicity in animal cells: Transport across cell membranes. Journal of Biotechnology, 1993, 30, pp. 339-350.

4. Britto, D.T.; Siddiqi, M.Y.; Glass, A.D.M.; Kronzucker, H.J. Futile transmembrane $\mathrm{NH}_{4}^{+}$cycling: A cellular hypothesis to explain ammonium toxicity in plants. Proceedings of the National Academy of Sciences USA, 2001, 98, pp. 4255-4258.

5. Britto, D.T.; Konzucker, H.J. $\mathrm{NH}_{4}{ }^{+}$toxicity in higher plants: a critical review. Journal of Plant Physiology, 2002, 159, pp. 567-584.

6. Müller, T.; Walter, B.; Wirtz, A.; Burkovski, A. Ammonium Toxicity in Bacteria. Current Microbiology, 2006, 52, pp. 400-406.

7. Brunning-Fann, C.S.; Kaneene, J.B. The effects of nitrate, nitrite, and N-nitroso compounds on human health. Veterinary and Human Toxicology, 1993, 35(6), pp. 521-538.

8. Weng, Y.M.; Hotchkiss, J.H.; Babish, J.G. N-nitrosamine and mutagenicity formation in Chinese salted fish after digestion. Food Additives and Contaminants, 1992, 9(1), pp. 29-37.

9. Bradberry, S.M.; Gazzard, B.; Vale, J.A. Methemoglobinemia caused by the accidental contamination of drinking water with sodium nitrite. Clinical Toxicology, 1994, 32(2), pp. 173-178.

10. Blackall, L.L., A Summary of Recent Microbial Discoveries in Biological Nutrient Removal from Wastewater. Australasian Biotechnology, 2000, 10(3), pp. 29-32.

11. Van Leeuwen, F.X.R. Safe drinking water: The toxicologist's approach. Food and Chemical Toxicology. 2000, 38(1), pp. 51-58.

12. Hu, X.M.; Chen, Y.W.; Liao, Y.G.; Yan, W.F.; Zhu, S.M.; Shen, S. B. High $\mathrm{NH}_{4}^{+}-\mathrm{N}$ concentration wastewater treatment by shortcut nitrification-denitrification using a system of A/O inner loop fluidized bed biofilm reactors. Water Science and Technology, 2013 67(5), pp. 1083-1091.

13. Sandu, M.; Spataru, P.; Arapu, T.; Lupascu, T. Biochemical oxidation - a pathway for ammonia removal from aquatic systems. Methods and Techniques for Cleaning-up Contaminated Sites, Annable, M.D.; Teodorescu, M.; Hlavinek, P.; Diels L. Eds. Springer: Sinaia, Romania, 2006, pp. 137-143.

14. ISO 7150-1:2001. Water quality - Determination of ammonium -Spectrometric method.

15. ISO 7890-3:1988. Water quality - Determination of nitrate - Part 3: Spectrometric method using sulfosalicylic acid.

16. ISO 8466-1:1990. Water quality - Calibration and evaluation of analytical methods and estimation of performance characteristics - Part 1: Statistical evaluation of the linear calibration function.

17. SR ISO 7890-3:2000 Water quality - The determination of the content of nitrates. The part 3: The spectrometric method with sulfosalicylic acid.

18. SM SR EN 26777:2006 Water quality - determination of the content of nitrites. The method of the spectrometry of molecular absorption.

19. Lozan, R.; Sandu, M.; Ropot, V. The method of determination of nitrites. RU Patent, 1990, No. 1638619 (in Russian).

20. Matveeva, N. P.; Klimenko, O.A.; Trunov, N. M. Simulation of self-purification of natural treatment of organic pollutants in the laboratory. Gidrometeoizdat: Leningrad, 1988, pp. 26-31 (in Russian).

21. Sandu, M.; Spataru, P.; Negru, M.; Mosanu, E.; Dragutan, D.; Goreacioc, T. The dynamic of nitrification process in the presence of cationic surfactants. International symposium "The Environment and Industry", Bucharest, 2007, vol. 1, pp. 277-281 (in Romanian).

22. Sandu, M.; Spataru, P.; Mosanu, E.; Tarata, A. Nitrification capacity water tributaries of the Prut River and the factors that influence. XXX-th Romanian Chemistry Conference, Romanian Academy, Calimanesti-Caciulata, Valcea, 2008, p. 384 (in Romanian).

23. Philip, S.; Laanbroek H. J.; Verstraete, W. Origin, causes and effects of increased nitrite concentrations in aquatic environments. Reviews in Environmental Science and Biotechnology, 2002, 1, pp. 115-141. 
24. Spataru, P. Transformations of organic substances in surface waters of Republic of Moldova. Ph.D. in Chemistry, State University of Moldova, Chisinau, 2011 (in Romanian).

25. Lewis, M. A. The effects of mixtures and other environmental modifying factors on the toxicities of surfactants to freshwater and marine life. Water Research, 1992, 26(8), pp. 1013-1023.

26. Cui, Z.G.; Cui, Y.Z.; Cui, C.F.; Chen, Z.; Binks, B. P. Aqueous foams stabilized by in situ surface activation of $\mathrm{CaCO}_{3}$ Nanoparticles via Adsorption of Anionic Surfactant. Langmuir, 2010, 26(15), pp. 12567-12574.

27. Cui, Z.G.; Cui, C.F.; Zhu, Y.; Binks, B. P. Multiple phase inversion of emulsions stabilized by in situ surface activation of $\mathrm{CaCO}_{3}$ nanoparticles via adsorption of Fatty acids. Langmuir, 2012, 28(1), pp. 314-320.

28. Atkin, R.; Craig, V.S.J.; Biggs, S. Adsorption kinetics and structural arrangements of cationic surfactants on silica surfaces. Langmuir, 2000, 16, pp. 9374-9380.

29. Sayari, A.; Hamoudi, S.; Yong, Y. Applications of pore-expanded mesoporous silica. 1. Removal of heavy metal cations and organic pollutants from wastewater. Chemistry of Materials, 2005, 17(1), pp. 212-216.

30. Morse, J.W. The surface chemistry of calcium carbonate minerals in natural waters: An overview. Marine Chemistry, 1986, 20(1), pp. 91-112.

31. Srinivasan, R.; Hoffman, W.D.; Wolfe III, J.E.; Prcin, L.J. Evaluation of removal of orthophosphate and ammonia from rainfall runoff using aboveground permeable reactive barrier composed of limestone and zeolite. Journal of Environmental Science and Health, Part A: Hasardous Substances and Environmental Engineering, 2008, 43(12), pp. 1441-1450.

32. Warren, L.A., Maurice, P.A. Microbially mediated calcium carbonate precipitation: implications for interpreting calcite precipitation and for solid-phase capture of inorganic contaminants. Geomicrobiology Journal, 2001, 18(1), pp. 93-115. 